\title{
The unique method to prevent hail
}

\author{
Ismailov Sokhrab Akhmedovic \\ Institute of Petrochemical Processes, Academy of Sciences of Azerbaijan, Baku
}

\section{Email address:}

sokhrab@yahoo.com

\section{To cite this article:}

Ismailov Sokhrab Akhmedovic. The Unique Method to Prevent Hail. Science Discovery. Vol. 2, No. 3, 2014, pp. 43-46. doi: $10.11648 /$ j.sd.20140203.11

\begin{abstract}
In contrast to the previous well-known theories of thunderstorm showers, in this paper, we propose a new hypothesis on the formation of hail, and an original and simple way to prevent hail with lightning rod. Lightning rod at the same time can prevent and hail, and lightning.
\end{abstract}

Keywords: Hail, Lightning-Rod, Helium, Air Balloon, Cloud

\section{Introduction}

The hail is one of the most terrible natural disaster causing damage to mankind. The fall of the hail, first of all, destroys the plants, kills livestock, as well as the man himself. The fact of the matter is that a sudden and large influx of offensive hail eliminates protection against it. In the United States the hail destroyed an average of 1 to $2 \%$ of crops. In some areas the figure is $6 \%$. Damage is $1-1.5$ billion Dolar United States [1]. Extremely great damage from hail in North America was registered in May 1995 in Texas (about \$2 billion). May 14, 2001 in Stavropol region of Russia hail damaged 4,500 homes, killed the agricultural crops area of $1000 \mathrm{sq} \mathrm{km}$ and perennials on the area of $30 \mathrm{sq} \mathrm{km}$, the damage reached \$17 million USA. The Midwest United States hit by storm. 12 Tornadoes recorded in the states of Nebraska, Iowa, Wyoming, and Kansas. In the town of Blair suffered 4,500 cars dealer network Woodhouse Auto Family. The total value of the damaged property is $\$ 152$ million [2]. It is no accident that when UNESCO had established a Special Commission on account of natural disasters-UNDRO (United Nations Disaster Relief Organization-disaster response by the United Nations).

In the Middle Ages and in the first half of the XIX century, there have been several suggestions to various researchers, such as, Boussingault, Swedes, Klossowski, Volta, Reye, Ferrel, Gan, Faraday, Zonke, Reynolds et al. Unfortunately, their theories have not received confirmation. It should be noted that and the recent opinions on this issue are not scientific evidence, and there is still no complete understanding of the mechanism of hail. About the formation of hail and its of negative consequences are given detailed information in the recently published articles [3-10].

\section{What Representations Exist to Prevent Hail}

It should be noted that,the reason for the formation of hail have been determined incorrect, the false views and the theories put forward till today. That is why, these scientists have been unable to prevent or avoid it. The major trends in this research is not to prevent hail,but to diminish it from a large part of the mass [11-17]. Thus, to this end, were used the various chemical reagents (eg, $\mathrm{CO}_{2}, \mathrm{AgI}, \mathrm{NaCl}$, tetraalkilamoniumun in freon solution, and so on) the rockets and the projectiles, as carriers. The aim of this difficult operation was: to create a large number of crystallization centers, with this way replaced hail with large mass with smaller particles and thus reduce the amount of damage caused.

In February 2010, the newspaper RIA "News" reported that the Moscow scientists have developed a new modified aircraft or so-called "multi-functional aviation complex" Nart ", designed to prevent catastrophic natural weather events, such as hail, torrential rain, tornadoes and typhoons, through active impacts on meteorological processes. According to the developers, the range influence of the complex is 300350 kilometers and has passed several tests in the south of Russia. Nevertheless, the use of this device produced no tangible results, Moscow and its region again are showered of hail with the size of the Greek walnut. 
General views on the mechanism of formation of hail known meteorologist since Descartes to the present day do not constitute reliable scientific validity and the available data in the literature no correct reflect the progress of the matter. The main part of generally accepted theory is based on the premise Wegener-Bergeron-Findeisen, which for a long time is recognized by the World Meteorological Organization and it is still in effect:

"Rising from the Earth's surface on a hot summer day, the warm air cools with height, and the moisture is condensed, formed a cloud. Cooled liquid droplets in the clouds are found even when the temperature is $-40{ }^{\circ} \mathrm{C}$ (at a height of about 8-10 $\mathrm{km})$. But these drops are very unstable. Raised from the Earth's surface the smallest particles of sand, salt, combustion products and even bacteria with super cooled drops disturb the fragile balance. Cooled liquid drops that came into contact with solid particles, turn into an iceembryo of hailstones. Small hailstones are in the top half of almost every cumulonimbus clouds rain, but most often such hailstones when approaching the Earth's surface are melting. So, if the speed of the upward flow in a cumulonimbus cloud reaches 40 $\mathrm{km} / \mathrm{h}$, they cannot keep the hailstones, therefore, passing through a warm layer of air at a height of 2.4 to $3.6 \mathrm{~km}$, they fall out of the clouds in the form of small soft hail or rain at all. Otherwise, the updrafts lift the small hailstones up to layers of air with temperature from $-10^{\circ} \mathrm{c}$ to $-40^{\circ} \mathrm{c}$ (height between 3 and 9 miles), a diameter of hailstones begins to grow, reaching sometimes several centimeters. It should be noted that in exceptional cases the speed of ascending and descending cloud flows can reach $300 \mathrm{~km} / \mathrm{h}$ ! And the higher the speed the upward flow in a rain cloud, cumulonimbus, the larger the hail For the formation of hailstones the size of a golf ball more than 10 billion needed super cooled water drops, and hailstone cloud must remain at least 5-10 minutes to reach such a large size. It should be noted that a single drop of rain is about a million such small super cooled droplets. Hailstones with a diameter of more than $5 \mathrm{~cm}$ in cumulonimbus clouds, which are very powerful rising air currents. It is thunderstorms produce tornadoes, heavy downpours and gusts. Hail usually falls when severe thunderstorms in the warm season, when the temperature on the surface of the Earth above $20^{\circ} \mathrm{C} "$.

The World Meteorological Organization in 1956 gave a definition of what a hail:

"Hail-precipitation in the form of spherical particles or pieces of ice (hailstones) with a diameter ranging from 5 to $50 \mathrm{~mm}$, sometimes more, falling separately or in the form of incorrect complexes. Hailstones consist only of transparent ice or of a number of layers with a minimum thickness of 1 $\mathrm{mm}$, alternating with translucent layers. Hail is observed usually in strong thunderstorms".

Almost all of the former and contemporary sources on the subject indicate that the hail is formed by a powerful concentrate the cloud at strong upward air flows. This is true. Unfortunately, most of the authors forget about lightning and thunderstorms. And the subsequent interpretation of the formation of hailstones, in our view, it is not logical and pointless.
In the review [17] emphasize that there is a relationship between parameters of the number of days with hail and thunderstorm. The authors clearly recognize that the hail is almost always falls during a thunderstorms and it is interesting to compare the parameters of the number of days with hail and thunderstorms. The comparison shows that there is quite a distinct and strong correlation between these parameters. Found that it in the years before the defense was 2.5:26.4 $=0.095$, and in the years protect 1.5:31 $=0.048$. However, recognize that, despite the continuous improvement of technical equipment and technological schemes impact hail albeit reduced, but each year brought significant damage to protected areas in all regions where the work was carried out. On this basis, it can be concluded that the current methods of influence on hail processes exhausted its possibilities. It should come up with a new type of hail of protection.

On the formation of hail and its adverse effects are given detailed information in recently published papers [3-10] and we strongly emphasize that in this context, the use of chemicals as a protective agent against the hail will not produce positive effects.

\section{As is Formed the Hail?}

We believe: "When the lightning begins due to the tremendous amount of heat, the water in the channel of lightning or around his intensely evaporates as soon as stop flashing lightning, it starts to freeze. In accordance with the known law of Physics: strong evaporation causes cooling. It is noteworthy that the heat during discharge of lightning is not imposed from the outside, on the contrary, it derives from the system itself (in this case system: polarized electrostatic water). The process of evaporation is the kinetic energy of the polarized water system. In this process, a strong and instant evaporation of water causes a sharp its solidification. The stronger the evaporation, the more intense is the process of solidification of water. For such a process is not necessary that the ambient temperature was below zero. The lightning discharge generates a variety the size of the hailstones. The hailstones depend on the power and intensity of lightning. The stronger and more intense lightning are, the larger the hailstone. Usually the hail stops as soon as quickly stops flashing lightning."

From the point of view of the authors of [17], developed in the sixties, scientists and specialists of several institutes and other academic institutions world missile way to impact on sedimentation processes of hailstorm voted the world's most efficient. According to them, the method most is appropriate to the modern concepts of physics and hail precipitation and management in order to prevent the growth of hail and increase rainfall. Its development has been invested efforts of large teams of scientists and much money. In addition, the implementation of this method requires an extremely high cash costs, to use of sophisticated equipment (radars, missiles, computers, etc.), the highest level of training and work organization. Nevertheless, even if all these conditions are 
realized often hail destroys crops and planting of large areas.

The above requirements it extremely difficult to implement. Need for new science-based, effective, but less complex and less expensive methods of process control in the clouds.

Methods is based the influence on cloud processes with the aim of suppressing the growth processes of hail. Works on the effects of clouds with a view to their scattering attenuation hail, precipitation increase are conducted in many countries for over 50 years. Nevertheless, the problem is so complex that their level of efficiency so far is controversial according to theorists and experimentalists.

In our view, a reasonable way to prevent hail to overcome or at least mitigate the lightning. We suggest using the following construct for this purpose (Fig.1.).

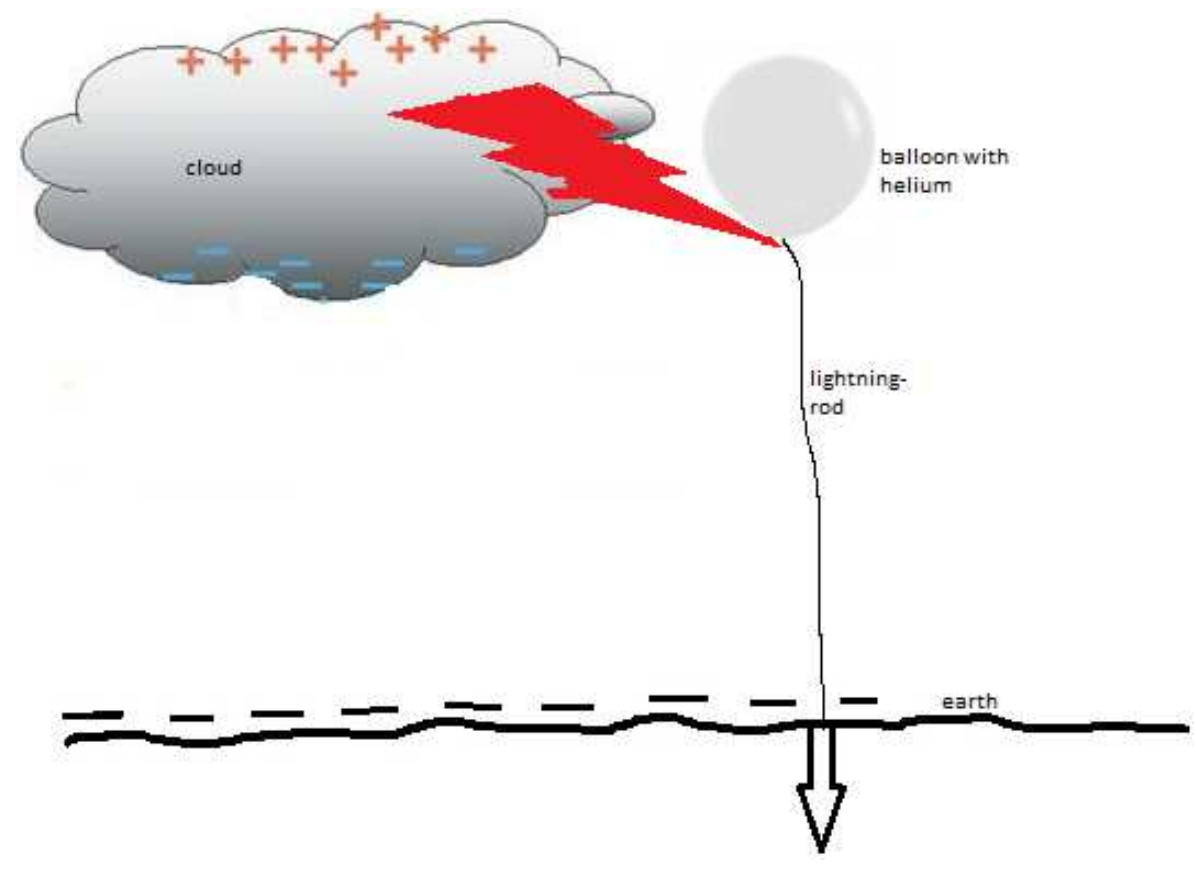

Figure 1. Construction to prevent lightning and hailstone

\section{How to Prevent Hail}

It is known that the only way to protect against lightning first developed in 1750, the American scientist, Benjamin Franklin. He showed that electric charges or a bolt of lightning can be easily and safely escort to the ground through the metal wires. The latter is called "lightning rod" and is actively used today. Regarding to this, his invention helps prevention of the hail *.

In this sense, this invention can help in the prevention of the hail *. So, one end of the cable connects to the protected ground ("grounding") and the other end fastened balloon, filled with helium. Then the balloon is released into the air. The greater the distance between the lightning-rod and the Earth (1-2 miles), the better the efficiency of the installation. In this case, the lightning rod closer to the cumulonimbus clouds and its effective conical effect will be even greater. Absolutely, electrical charges accumulated in the cloud will descend through a metal wire is easier than through the airspace or water layer. Here is the principle.

As for the engineering, construction and Assembly, this question gets their decision in other more specific professionals.

*Simple working principle of lightning rod is not mentioned here, because it has the necessary amount of information in the scientific literature.

\section{Conclusions}

1. Reason for the formation of hail is the origin of the instant and huge amount of heat from lightning in cumulonimbus clouds. Powerful heat generated by lightning leads to a strong evaporation of the water in the channel and around the zipper. Strong evaporation of water leads to rapid cooling water to form ice, respectively.

2. For such a process is not necessary that the ambient temperature was below zero.

3. The hailstones depend on the power and intensity of lightning. The stronger and more intense lightning are, the larger the hailstone.

4. On the basis of our new theory, the only tool to prevent hail is a lightning rod.

5. The chemicals in these conditions will not act against hail.

\section{References}

[1] Changnon S.A., 1997, Climatology of hail risk in United States, CRR-40, Changnon Climatologist, Mahomet, Illinois, pp. 1- 89 .

[2] Hill C., 1996, Mayday!. Weatherwise, June/July 25-28. 
[3] Ismailov S.A. A new hypothesis about the mechanism of the hail formation. //Meždunarodnyj naučno-issledovatel'skij žurnal. 2014. No.6. (25). Part 1. pp.9-12;

[4] Ismailov S.A. About the building mechanism of hail showers.// Universum7universum.com/en/tech/archive/item/1 463 ;

[5] Ismailov S.A. About the building mechanism of hail showers.// www.academia.edu/7789706/;

[6] Ismailov S.A. About the building mechanism of hail showers.// www.hexachlorocyclopentadiene.jimdo.com ;

[7] Ismailov S.A. A new hypothesis about the mechanism of the hail formation.//www.hexachlorocyclopentadiene.jimdo.com;

[8] Ismailov S.A. About the mechanism of the hail formation.// IntellectualArchive. July 2014. Vol. 3. No. 4. pp. 58-77.

[9] Ismailov S.A. About the mechanism of the hail formation.// Problems of modern science and education. Moscow, 2014. No.2. (20). pp.16-27.

[10] Ismailov S.A. About the Mechanism of the Hail Formation.// Science Discovery. 2014, Vol. 2, No. 2, pp. 27-33.

[11] Abshaev M.T. On a new method effects on hail processes. Scientific works; of the WGI.1989, V.72, pp.14-28.
[12] Bibilashvili N. Sh., Bourtsev I.I., Seregin N.A. Guidelines for the organization and conducting anti-hail work. L.: Gidrometeoizdat, 1981, 168 p.

[13] Tlisov M.I., Kagermazov A.H. Statistical analysis of the special hail measuring network during the active effects and in their absence, based on grades / in the book. "Review of Industrial and Applied Mathematics" - M.: Scientific Publishers "RTA", 1995, Vol. 2, No.2. pp.187-194.

[14] Tlisov M.I., Khuchunaev B.M. "Physical characteristics of Hail from naturally developed and seeded cloud processes. Recommendations on modification of present hail suppression Methods // 12-th International Conference on Clouds and Precipitation Zurich, Switzerland, 19-22 August 1996, Proceedings - Vol. 1, pp. 1275-1276.

[15] Tlisov M.I., Huchunaev V.M. Patent RU 2119741. Method for preventing the formation large hail in the clouds.

[16] Beytuganov M.N .; Zalikhanov M.CH .; Romanov VG Patent RU 2076579. Method prevent hail.

[17] Dinevich L., Kamalov B. Ways of optimization methods to influence the processes formation of precipitation. // Modern high technologies. - 2013. No.12. pp. 94-100. 